\title{
Acceptability and perceived side effects of insecticide indoor residual spraying under different resistance management strategies
}

\author{
Américo David Rodríguez, PhD, (1) Rosa Patricia Penilla, PhD, (1) Mario Henry Rodríguez, PhD, (2) \\ Janet Hemingway, PhD, ${ }^{(3)}$ Antonio Trejo, MSc, ${ }^{(1)}$ Juan Eugenio Hernández-Avila, MSc.(4)
}

\begin{abstract}
Rodríguez AD, Penilla RP, Rodríguez MH, Hemingway J, Trejo A, Hernández-Avila JE.

Acceptability and perceived side effects of insecticide indoor residual spraying under different resistance management strategies. Salud Publica Mex 2006;48:317-324.
\end{abstract}

\begin{abstract}
Objective. To assess household acceptability and perceived side effects of residual indoor pyrethroid (PYR), carbamate and organophosphate insecticides sprayed by annual rotation (ROT), spatial mosaic (MOS), and a single insecticide (DDT or PYR) in communities of the coastal plain of Chiapas, Mexico. Material and Methods. A questionnaire to assess the acceptability and perceived side effects of indoor insecticides was administered to one member of $30 \%$ of the families in eight villages of Chiapas. The association of different insecticide treatments with their responses was evaluated (Chi-square). The intensity of side effects indicated under different treatments was compared in an ordered logistic model, using a severity index as the response variable. Results. Insecticide spraying as a probable cause of symptoms was identified by $2.1 \%$ of interviewees. A significantly high percentage of persons with blurred vision, dizziness, sneezing, coughing, numbness, watery eyes, and itching lived in villages under MOS and ROT and a high severity index was significantly associated with ROT treatment. Reduction of mosquito bites and cockroaches were the perceived main benefits, and most villagers that perceived no benefits lived in DDT treated villages. Most of the interviewees welcomed spraying (83.7\%), but the smell and having to re-
\end{abstract}

Rodríguez AD, Penilla RP, Rodríguez MH, Hemingway J, Trejo A, Hernández-Avila JE. Aceptabilidad y efectos secundarios percibidos del rociado residual intradomiciliario de insecticidas bajo diferentes esquemas de manejo de resistencia. Salud Publica Mex 2006;48:317-324.

\section{Resumen}

Objetivo. Evaluar la aceptabilidad y los efectos secundarios del rociado intradomiciliar de insecticidas pyrethroides (PYR), carbamato y organophosphato rociados en rotación anual (ROT), en mosaico espacial (MOS), o solos (DDT o PYR) en hogares de comunidades de la costa de Chiapas. México. Material y métodos. Se aplicó un cuestionario a un miembro de $30 \%$ de las familias de ocho localidades de Chiapas para evaluar aceptabilidad y efectos secundarios del rociado. Se usaron análisis de ji cuadrada para determinar la asociación de los insecticidas rociados con las respuestas y se comparó la intensidad de efectos secundarios referidos bajo los diferentes tratamientos en un modelo logístico ordenado usando un índice de severidad como variable de respuesta. Resultados. Los insecticidas rociados como causa probable de síntomas fueron referidos por $2.1 \%$ de entrevistados, pero $12 \%$ de ellos asociaron los síntomas con otras causas. Un porcentaje significativamente alto de personas que refirieron visión borrosa, vértigo, estornudos, tos, entumecimiento, lagrimeo y comezón vivía en bajo MOS y ROT, mientras que el índice de severidad se asoció con el rociado ROT. La reducción en la picadura de mosquitos y en el número de cucarachas fueron los principales beneficios percibidos, y la mayoría de los

(I) Centro de Investigación de Paludismo, Instituto Nacional de Salud Pública (INSP), Tapachula, Chiapas, México.

(2) Centro de Investigación sobre Enfermedades Infecciosas, INSP, Cuernavaca, Morelos, México.

(3) Liverpool School of Tropical Medicine, Pembroke Place. UK.

(4) Department of Informatics and Geographic Medicine, INSP, Cuernavaca, Morelos, México. 
move furniture from houses were the main arguments against it. Conclusions. Acceptability correlated with insecticide spray coverage, although the most frequent suggestion for improvement was to increase the understanding of the objectives of spraying in the communities. The frequency of side effects was low, but higher in localities where a combination of insecticides was applied.This is a limitation for the use of this type of resistance management strategy in public health.

Key words: indoor insecticide spraying, acceptability, sideeffects, Mexico lugareños que no percibieron los beneficios vivía en localidades tratadas con DDT. La mayoría de entrevistados aceptaron bien el rociado (83.7\%), pero el mal olor y tener que sacar los muebles de las casas fueron los argumentos principales en contra. Conclusiones. La cobertura de rociado correlacionó con la aceptabilidad, aunque la sugerencia más frecuente para incrementarla fue la de explicar los objetivos del rociado en las comunidades. La frecuencia de efectos secundarios fue baja, pero mayor en localidades donde se aplicó una combinación de insecticidas, lo que representa una limitación para el uso de esta estrategia de manejo de resistencia a estos químicos en salud pública .

Palabras clave: insecticida, rociado intradomiciliar, aceptabilidad, efectos secundarios, México
C ommunity acceptability is required for the implementation of disease vector control programmes, and it is particularly relevant in indoor residual spraying. Spraying coverage depends on whether householders perceive the intervention as beneficial, in terms of how effective the insecticide is against mosquitoes and other nuisance insects, as well as the number and intensity of unwanted side effects. ${ }^{1,2}$

The perceived side effects of insecticide indoor spraying could motivate a poor acceptance of these types of interventions. Side effects are more commonly reported in insecticide spraying personnel, ${ }^{3-7}$ but some minor side effects have been observed in villagers exposed to some indoor sprayed insecticides. $5,6,8$ Side effects vary with the chemical type of the insecticide used ${ }^{5,9,10}$ and their residuality. ${ }^{9}$ Humans exposed to pyrethroids may experience abnormal skin sensations and upper respiratory irritation, ${ }^{11,12}$ as well as sneezing and coughing. ${ }^{5}$ The most common symptoms associated with organophosphates are headache, dizziness, fatigue, nausea, breathing problems, abdominal cramps and tingling in extremities. ${ }^{9,10}$

Meanwhile, more rational methods for applying insecticides are necessary to avoid or halt the increasing resistance to the available chemicals used in the control of insect disease vectors. The application of insecticides in a mosaic pattern (MOS), or their rotation (ROT), proposed as strategies for insecticide resistance management, ${ }^{13}$ require the use of more than one chemical type of insecticides. Besides their effectiveness in resistance management, prior to the upscale of implementation, the community acceptability of spraying strategies is a very important aspect needing evaluation, as the perceived side effects of insecticides and their acceptability by villagers could be a decisive fac- tor in choosing the types of insecticides to be included in the programme.

We report herein the results of a survey on insecticide spraying acceptability conducted in villages from an area where an insecticide resistance management programme was under evaluation. As insecticides of four different chemical classes were being used in the programme, along with investigating acceptability of the different treatments, information on the villagers' perceived side effects of the treatment was also obtained.

\section{Material and Methods}

The study was conducted in an area of the coastal plain of Chiapas, Mexico while insecticide resistance management strategies were under evaluation. ${ }^{14}$ Annual rotation (ROT) of three different classes of insecticides (organophosphate [OP], pyrethroid [PYR], and carbamate [CARB]) and spatial mosaic spraying (MOS) of two different classes of insecticides (OP and PYR) were compared with the use of a single insecticide (DDT or PYR) (Figure 1). The project and letters of informed consent signed by each participant before entering the study were approved by the Ethics Committee of the National Institute of Public Health. Previous to the insecticide application villagers were asked to remove their furniture, cooking utensils and food and were advised to avoid entering their houses for at least one hour after the application of the insecticide.

Questionnaires to investigate perceived side effects and acceptability were administered in eight of the 24 study villages from April to May of 1998 (two villages per treatment and all four insecticide classes were included in the resistance management programme) (Ta- 


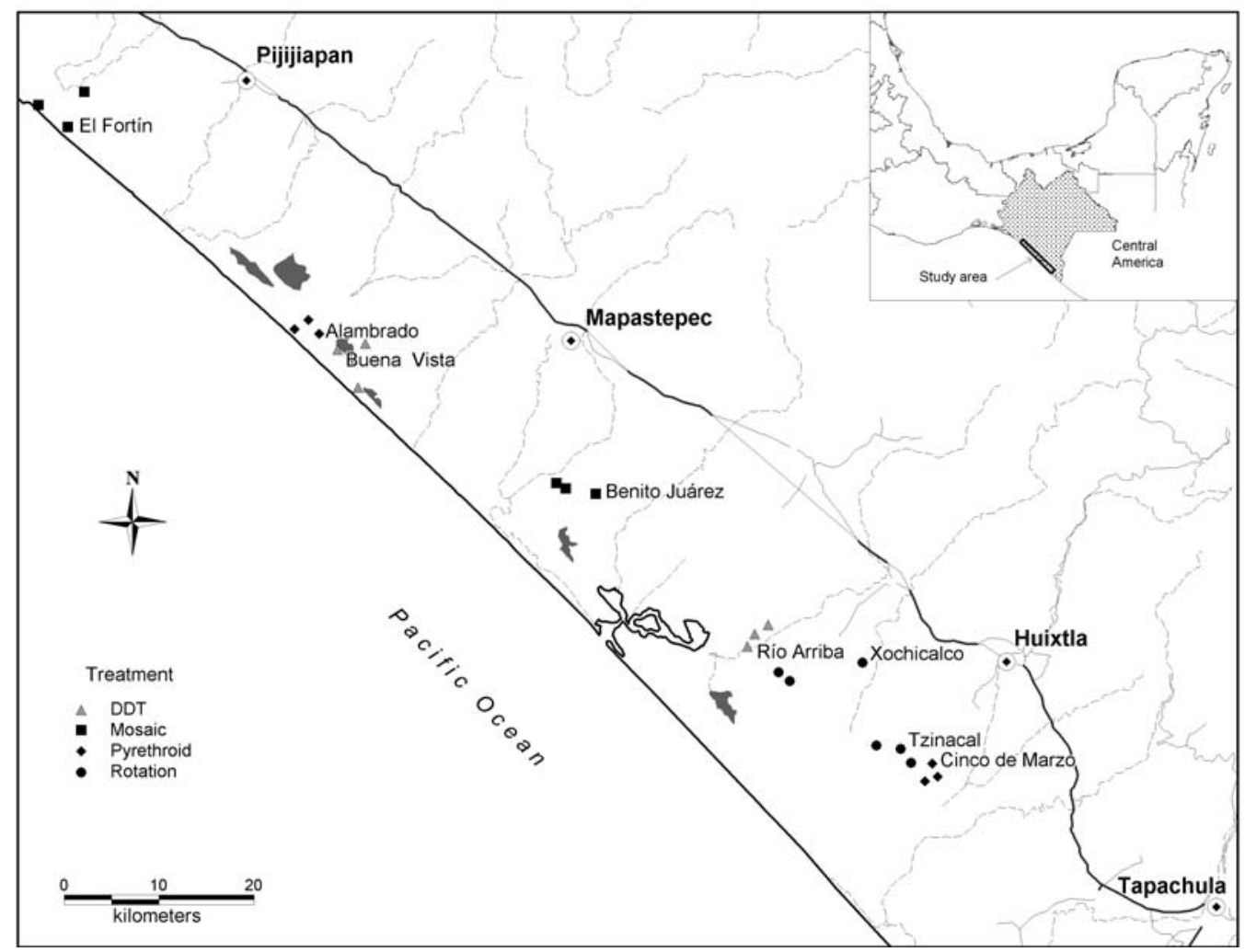

Figure I. Map of the Chiapas coastal area (With insert indicating the location of the study area) indicating THE VILLAGES, AND THEIR CORRESPONDING TREATMENT GROUP, WHERE THE QUESTIONNAIRES WERE APPLIED IN 1998

ble I). The number of households included in the survey varied among villages depending on the availability of respondents. At least $30 \%$ of the families per village was included and, in some small villages, all families were interviewed. The number of families per locality ensured detection of significant differences at 95\% confidence level. Trained interviewers administered questionnaires to one member of each family who indicated having good knowledge of the family and who agreed to be interviewed.

Previous to the application of the questionnaire, our interest in retrieving information in order to aid in future planning of insecticide spraying programmes was explained. The questionnaire consisted of three parts: One series of questions retrieved information on the family structure, the occupation of each member and the time they waited before entering the house after the spraying was conducted; a second series of questions enquired about symptoms in any family mem- ber that could be related to insecticide exposure, their duration and their perceived causes;, 910,15 and the third section included a series of specific questions about their perceived direct and secondary benefits, and unwanted effects of insecticide spraying.

To diminish the hesitance of interviewees to respond with possibly contentious answers, they were asked about their opinion on why other villagers refuse insecticide spraying, and a list of possible causes (smell, irritation or other health problems, poisoning of domestic animals, having to take the furniture outside, stains the walls, creates disorder, is a waist of time, other) was offered. It is believed that their answers mostly reflected the interviewees' own perceptions of the discomforts caused by spraying. What they would change about the spraying activities to improve acceptability was a final open question. In this context, acceptability was assessed using three parameters: non-refusal to indoor spraying, perceived beneficial 
Table I

\section{DATES, DAYS AFTER SPRAYING AND NUMBER OF QUESTIONNAIRES ADMINISTERED PER VILLAGE PER TREATMENT IN LOCALITIES ON THE COASTAL PLAIN of Chiapas, Mexico in 1998}

\begin{tabular}{|c|c|c|c|c|c|}
\hline Village & Treatment & $\begin{array}{c}\text { Last spray } \\
\text { date }\end{array}$ & $\begin{array}{c}\text { Ques. } \\
\text { admin. date }\end{array}$ & $\begin{array}{l}\text { Days } \\
\text { after }\end{array}$ & $\begin{array}{l}\text { Ques. } \\
\text { admin. }\end{array}$ \\
\hline I. Alambrado & Pyrethroid & 19/Feb/98 & 8/May/98 & 79 & 30 \\
\hline 2. Benito Juárez & Mosaic & $31 /$ Mar/98 & 7/Apr/98 & 7 & 21 \\
\hline 3. Buena Vista & DDT & 14/Mar/98 & 9/May/98 & 55 & 30 \\
\hline 4. E. Río Arriba & DDT & 12/Mar/98 & I3/Apr/98 & 31 & 22 \\
\hline 5. Fortín & Mosaic & 27/Mar/98 & 7/Apr/98 & 10 & 24 \\
\hline 6.5 de Marzo & Pyrethroid & 20/Feb/98 & 8/Apr-98 & 48 & 25 \\
\hline 7.Tzinacal & Rotation & 3/Mar/98 & 18/Apr/98 & 45 & 30 \\
\hline 8. Xochicalco & Rotation & 6/Mar/98 & 7/May/98 & 61 & 30 \\
\hline
\end{tabular}

effects and discomforts. In other vector control interventions, ${ }^{16}$ acceptability is usually measured according to the house coverage in the community. Indoor residual spraying is better accepted if villagers perceive any benefit from it.

Chi-square analyses ${ }^{17}$ were used to assess any effect of different insecticide treatments on the responses given by interviewees in the last two sections of the questionnaire. An index of severity of side effect symptoms was built according to the number of symptoms indicated by interviewed subjects. Severity was categorized as high if headache, abdominal pain, vomiting or nausea was accompanied by at least another symptom and mild when only one symptom was mentioned. To compare the intensity of side effects in the human populations among different insecticide treatments, an ordered logistic model ${ }^{18}$ was fitted to the data using the categorized severity index as the response variable, and insecticide treatments as predictors. An ordered logistic model is an extension to the logistic model that allows modelling data where the response variable is an ordinal one with more than two possible outcomes. The model was adjusted for the time elapsed between insecticide spraying and the interview date and also for the reported waiting time before entering the house after spraying.

\section{Results}

Demographic information. A total of 200 people were interviewed, one corresponding to each family; 125 $(62.5 \%)$ were females and $75(37.5 \%)$ males. The age of interviewees ranged from 18 to 78 years (mean of $39.2 \pm 13.7 \mathrm{SD}$ years). The highest percentage (39.2\%) of females was between 25 and 40 years old, while the highest percentage of males $(46.6 \%)$ was between 40 and 55 years old. There were on average 5.1 inhabitants per house (range 1-13). Interviewees included the mother $(58.0 \%)$, the father $(35.5 \%)$, the eldest son $(3.0 \%)$, the eldest daughter $(2.0 \%)$ or the grandmother $(1.0 \%)$. The most frequent occupations of interviewees were housewives $(58.5 \%)$, farmers $(18.0 \%)$ and fishermen $(16.5 \%)$. Most interviewees had incomplete elementary education ( $40.8 \%$ females and $38.6 \%$ males), $22.5 \%$ were illiterate (20.8\% females and $25.3 \%$ males) and $4.0 \%$ had completed high school or above $(0.8 \%$ females and $9.3 \%$ males).

No significant differences in the time waited to enter houses after spraying occurred among villages treated with DDT, PYR and MOS ( $p>0.05)$, but the waiting time was significantly lower in the localities under ROT $(p=0.022)$. The average time villagers waited to enter their houses was 92 minutes (111.2 SD, range $=12$ minutes to 24 hours). Most of the villagers $(51.7 \%)$ entered their houses between one and two hours after spraying, $21.5 \%$ entered between two and three hours and $15.6 \%$ entered before the first hour. Villagers from the villages treated with DDT waited on average $110.2( \pm 203.4 \mathrm{SD})$ minutes, those in MOS villages waited 111.1 ( \pm 71.5 SD) minutes, in PYR treated villages the wait was $83.6( \pm 42.6 \mathrm{SD}) \mathrm{min}-$ utes and villagers waited $70.6( \pm 64 \mathrm{SD})$ minutes in ROT treated villages.

Symptoms possibly associated with pesticide exposure. Seventy per cent of the interviewees reported at least one of the symptoms researched in the study, and $40 \%$ of the households were classified in the high severity category. The symptoms most frequently listed (Table II) were headache $(33.5 \%)$, abdominal pain $(21.6 \%)$, dysuria $(18.9 \%)$ and vomiting $(8.1 \%)$ in persons over five years old. Vomiting was also cited in children under five-years-old (5.7\%). The most lasting symptoms were itching ( $240 \pm 153$ hours), sneezing (94 \pm 95.5 hours), coughing ( $87 \pm 63.7$ hours) and numbness (78 \pm 68.9 hours); however, these were the less frequently referred symptoms.

The probable causes of symptoms most frequently listed by villagers were sun exposure $(39.3 \%$, for headache, nausea, blurred vision, dizziness, ringing ears, sneezing, coughing, dysuria, and watery eyes), food poisoning $(17.7 \%$, for vomiting, abdominal pain and itching), parasites (15\%, for itching), flu (13.8) and other causes (10.4\%, for finger numbness) (Table III). Insecticide spraying was adduced as a cause by only $2.1 \%$ of the interviewees reporting symptoms. Among the other causes listed were allergy, Parkinson's disease, and excess of work. 
Table II

DISTRIBUTION OF MOST COMMON SYMPTOMS BY AGE, DURATION OF SYMPTOMS LISTED BY THE INTERVIEWEES of households in localities on the coastal plain of Chiapas, Mexico in 1998

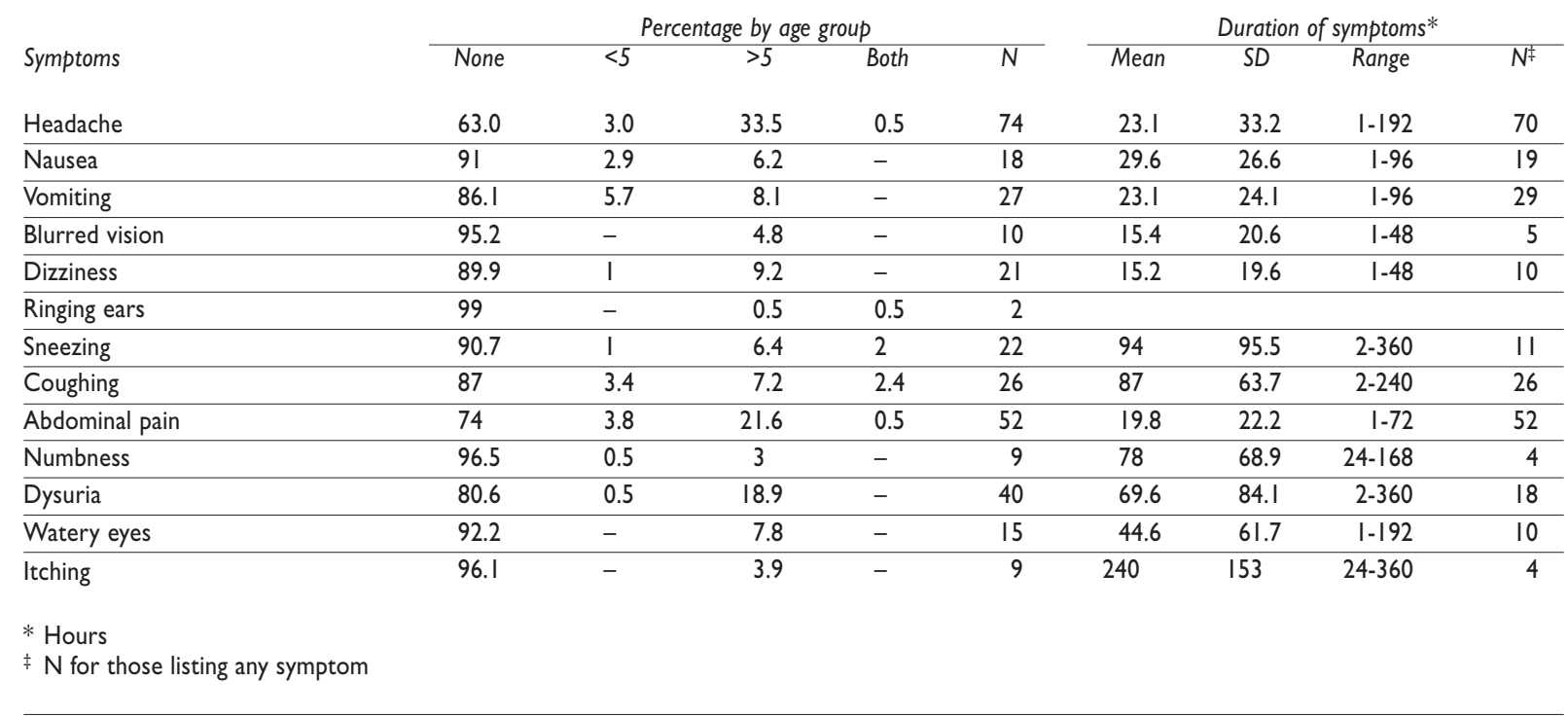

\section{Table III}

SYMPTOMS AND THEIR COMMON CAUSES LISTED By I $2.5 \%$ OF INTERVIEWEES OF HOUSEHOLDS IN LOCALITIES on the coastal plain of Chiapas, Mexico in 1998

\begin{tabular}{|c|c|c|c|c|c|c|c|c|c|c|}
\hline Symptoms & $n^{*}$ & Spray & Sun & Food & Parasites ${ }^{\ddagger}$ & Flu§ & Blood pressure & Quick-temper & Other & Don't know \\
\hline Headache & 74 & 1.3 & 50 & 7.9 & 10.5 & 13.2 & 2.6 & 3.9 & 9.2 & 1.3 \\
\hline Nausea & 18 & 5.6 & 27.8 & 22.2 & 22.2 & II.I & - & - & II.I & - \\
\hline Vomiting & 27 & - & 13.8 & 34.5 & 27.6 & 6.9 & - & - & 13.8 & 3.4 \\
\hline Blurred vision & 10 & - & 50 & 10.0 & 20 & 20 & - & - & - & - \\
\hline Dizziness & 21 & 4.8 & 42.9 & 14.3 & 19 & 9.5 & 4.8 & - & 4.8 & - \\
\hline Ringing ears & 2 & - & 100 & - & - & - & - & - & - & - \\
\hline Sneezing & 22 & 14.3 & 19 & 14.3 & 14.3 & 33.3 & - & - & 4.8 & - \\
\hline Coughing & 26 & 7.4 & 22.2 & II.I & 7.4 & 44.4 & - & - & 3.7 & 3.7 \\
\hline Abdominal pain & 52 & - & 29.6 & 33.3 & 16.7 & 9.3 & - & - & 9.3 & 1.9 \\
\hline Numbness & 9 & - & - & 22.2 & 33.3 & II.I & - & - & 33.3 & - \\
\hline Dysuria & 40 & 2.4 & 85.4 & 4.9 & 4.9 & 2.4 & - & - & - & - \\
\hline Watery eyes & 15 & 12.5 & 37.5 & 25 & 6.3 & 12.5 & - & - & 6.3 & - \\
\hline Itching & 9 & II.I & II.I & 33.3 & 44.4 & - & - & - & - & - \\
\hline
\end{tabular}

\footnotetext{
* Number of answers listing the possible causes for each symptom

‡ Includes "parasites","sickness", "infection" and "typhoid" as the specific causes

$\S$ Includes "flu", "cold", "dust" and "heat" as specific causes
}

A significantly higher percentage of people with blurred vision $(70 \%)$, dizziness $(52 \%)$, sneezing $(59 \%)$, coughing $(59 \%)$, numbness $(67 \%)$, watery eyes $(59 \%)$ and itching $(56 \%)$ occurred in villages under the MOS (OP and PYR) $(p<0.05)$; while a significantly higher percentage of people with dysuria were from villages under the ROT (OP, PYR, and CARB) and the PYR treatments (40 and 33\%, respectively, $p<0.05$ ). No significant differences among treatments were found in the percentage of people with headache, nausea, vomiting, ringing ears, and abdominal pain, $(p>0.05)$. The results of the ordered logistic model indicated a posi- 
tive association between the report of symptoms in the household and the different insecticide spraying treatments. High severity index in households was associated with ROT treatment.

The probability of finding a house with high severity index was higher in villages under ROT treatment $(\mathrm{OR}=3.2795 \% \mathrm{CI}=[1.46,7.34])$ compared to villages treated with DDT. Other treatments did not show any significant association with the severity index (Table IV). The estimated probabilities for the severity index according to the insecticide treatment are presented in Table V.

Acceptability of insecticide spraying. When asked about the benefits of residual spraying, $81.1 \%$ of villagers responded that it was useful in reducing mosquito bites, $8.5 \%$ responded that it reduced cockroaches and $6.6 \%$ indicated no benefits (Table VI). Significant differences occurred among respondents under different treatments $\left(\chi^{2=} 30.556, \mathrm{DF}=6, p<0.0001\right)$. Of those respondents associating spraying with a reduction in cockroaches, $77.7 \%$ were under the ROT strategy. Fifty percent of those responding that there was no benefit

Table IV

Ordered logistic model Results FOR THE SEVERITY INDEX

\begin{tabular}{lcc} 
Variable & Odds Ratio & [95\% Conf.Interval] \\
DDT & 1 & \\
\hline MOS & 0.71 & $(0.21-2.37)$ \\
\hline PYR & 1.58 & $(0.64-3.98)$ \\
\hline ROT & 3.27 & $(I .46-7.34)$ \\
\hline Log (waiting time) & 1.96 & $(1.26-3.07)$ \\
\hline Days after spraying & 0.98 & $(0.96-1.01)$ \\
Acilliary parameters & & \\
lcutl & & \\
\hline lcut2 & -1.24211 & $(-2.45,-0.04)$ \\
\hline
\end{tabular}

Table V

ESTIMATED PROBABILITIES FOR THE SEVERITY INDEX BY TREATMENT ACCORDING TO THE ORDERED LOGISTIC MODEL

\begin{tabular}{llll}
\multirow{2}{*}{ Treatment } & \multicolumn{3}{c}{$\begin{array}{c}\text { Severity Index } \\
\text { Low }\end{array}$} \\
\cline { 2 - 4 } DDT & 0.3657657 & 0.308252 & High \\
\hline MOS & 0.275268 & 0.3043891 & 0.3259823 \\
\hline PYR & 0.3483842 & 0.3077506 & 0.3438653 \\
\hline ROT & 0.2023761 & 0.2789359 & 0.518688
\end{tabular}

Table VI

BENEFITS FROM INDOOR RESIDUAL SPRAYING LISTED BY INTERVIEWEES OF THE HOUSEHOLDS IN LOCALITIES on the coastal plain of Chiapas, Mexico in 1998

\begin{tabular}{lrrrrrr} 
& \multicolumn{2}{c}{ Major } & & \multicolumn{2}{c}{ Additional } \\
\cline { 3 - 4 } \cline { 6 - 7 } Benefits from indoor spraying & $N$ & Percent & & $N$ & Percent \\
Reduce mosquitoes & & & & \\
\hline Reduce cockroaches & 172 & 81.1 & & 10 & 5.1 \\
\hline Reduce rats & 18 & 8.5 & & 76 & 39 \\
\hline Prevent malaria & 2 & 0.9 & & 7 & 3.6 \\
\hline Other benefits & 2 & 0.9 & & 14 & 7.2 \\
\hline None & 14 & 6.6 & 74 & 37.9 \\
\hline Total & 212 & 100 & & 195 & 100
\end{tabular}

were under DDT treatment. Only 1.9\% associated the spray with malaria transmission prevention.

When villagers were asked about benefits in addition to those first mentioned, malaria prevention increased to $7.2 \%$ and $39 \%$ listed reduction in cockroaches, but $37.9 \%$ responded that there was no other additional benefit (Table IV). Significant differences occurred among treatments $\left(\chi^{2=} 30.059, \mathrm{DF}=15, p=0.0117\right)$, where $50 \%$ of those indicating malaria prevention and $50 \%$ of those listing reduction in mosquitoes were from villages under ROT, and the lowest percentage $(9.2 \%)$ of those listing reduction in cockroaches were from the MOS treatment.

Most interviewees $(83.7 \%)$ welcomed spraying, indicating that there was nothing they disliked about it. Half $(4.3 \%)$ of the villagers who disliked spraying complained about the smell and $2.4 \%$ disliked having to remove furniture from the house. Other observations included a lack of insecticide effect, irritation and dizziness resulting from the insecticide exposure. Significant differences were detected $\left(\chi^{2=} 17.351, \mathrm{DF}=3, p=\right.$ $0.0006)$ when the two most frequent responses (nothing against it and bad smell) were compared by treatment; the highest percentage $(61.1 \%)$ of respondents that disliked the smell and the lowest percentage $(18.3 \%)$ that listed nothing against the insecticide came from villages under MOS.

In the opinion of those interviewed, the three most common causes of why other villagers refuse insecticide spraying were that: they disliked taking their furniture out of the house (35\%), the smell (35\%) and the disorder that it provokes $(11 \%)$. The responses were statistically different between treatments $\left(\chi^{2=} 22.142\right.$, $\mathrm{DF}=12, p=0.036$ ). Compared to other treatments, removing the furniture and the disorder were significantly lower in the MOS treatment (11 and 13.6\%, respectively). While poisoning of pets was significant-

salud pública de méxico / vol.48, no.4, julio-agosto de 2006 
ly lower $(6.3 \%)$ and "a waist of time" was more frequently listed (40\%) in villages under DDT. Allergies and sickness, concerns about possible dangers for their babies and poor knowledge about insecticide spraying were other causes listed for refusal.

Numerous answers were received to the open question on what they would change about the spraying activities to improve acceptability. The most common suggestions were to improve the understanding of the procedure in the communities (32\%) and to change the smell of the insecticides (15\%). Twelve percent responded that "complaints will never change" and $7 \%$ said to "spray with the furniture inside". Changing the insecticide was suggested by $4 \%$, "not to kill domestic animals" by another $4 \%$, "do nothing" was suggested by $7 \%$ and $4 \%$ did not know what could be changed. No significant differences were found when the most common suggestions were compared by treatment $(p>0.05)$. However, a higher percentage among those suggesting not to kill domestic animals (43\%) and to improve understanding (40\%) was in the ROT treatment. The highest percentages of those suggesting changing the smell of the insecticide were in the MOS $(39 \%)$ and the ROT treatments (29\%).

\section{Discussion}

Villagers referred to a series of symptoms that could be related to insecticide exposure under different insecticide spraying strategies. Headache, abdominal pain, dysuria and vomiting were the most frequently listed; while the less frequent, but most lasting, were itching, sneezing, coughing, and finger numbness. Although most interviewees associated these symptoms with sun exposure, food poisoning and parasites, a severity index was constructed in order to analyze their frequency in relation to the type of insecticide and the spraying methods applied in the villages. Symptoms and severity index level varied according to the spraying treatment. High severity level was more frequent in ROT than in all other treatments. In villages under ROT a combination of OP, CAR and PYR were used and accordingly, the most frequent symptoms listed were a mixture of those previously associated with exposure to OP (dizziness, coughing and numbness) and PYR (sneezing, watery eyes and itching). 5,9-12 The variability in the symptoms associated with different insecticides indicates that although unrecognized by villagers, insecticide side effects were occurring. Because of the exposure to the same insecticide, it would be expected that in the ROT and in the PYR treatments, villagers would have listed similar symptoms at the same frequency; however, a higher severity index lev- el in ROT- treated villages opens the possibility of an additive effect of OP, CAR and PYR in these localities.

On the other hand, some of the symptoms were listed more frequently during the pre-intervention period ${ }^{19}$ than during intervention, suggesting that some symptoms could result from non-occupational exposure to insecticides. This consideration is of relevance, as according to a pre-intervention questionnaire, in MOStreated villages a significantly higher percentage of villagers used insecticides for agricultural pests than in other villages in the study. In any case, further studies using direct measures to detect intoxication by pesticides are required to link symptoms with insecticides and their sources.

High coverage linked with acceptability are required for the success of vector control interventions. ${ }^{16}$ The acceptability of indoor residual spraying is related to whether householders perceive it as beneficial. In our study area, villagers' expectations were high before the spraying intervention: $98 \%$ of them agreed with indoor residual spray and $64 \%$ expected a reduction in mosquito bites. ${ }^{19}$ After two years of spraying, villagers were more aware of the advantages and disadvantages of indoor spraying, and the proportion (81\%) of interviewees that perceived a reduction in mosquito bites as its main benefit increased, but a reduction occurred among those that found nothing they disliked $(84 \%)$ and agreed with the spraying. This proportion was similar to the $80 \%$ of spraying coverage in the villages where the questionnaire was administered, and could reflect its relationship with the acceptance of the intervention.

The causes for refusal vary depending on the insecticide sprayed. In India, where most vector control is still based on DDT indoor spraying, the general opinion is against the usefulness of this insecticide, thus the coverage is poor. ${ }^{20}$ In our study, $50 \%$ of those responding that there was no benefit from spraying came from the DDT-treatment villages. Complaints about poisoning domestic animals were significantly lower in the same villages, while the "wasting of time" respondents were significantly higher, linking complaints in these villages with the lower efficacy of this insecticide. Conversely, the greatest numbers of interviewees that listed a reduction in cockroaches as a benefit from spraying came from ROT-treated localities, linking the reduction of the multi-insecticide resistance pest with the intervention and its acceptance.

Only a low percentage of interviewees mentioned specific aspects that they disliked about the spraying, probably because of shyness or fear to express their own opinions. Complaints increased when asked why, in the respondent's opinion, other villagers refuse the spray- 
ing, and the most common answers were: the smell of the insecticides, having to remove the furniture and the consequent disorder in the house. A noticeable result was that the dislike of insecticide smell was significantly more frequent in spraying treatments (MOS and ROT) that included an OP. Accordingly, to improve spraying acceptability villagers suggested changing the smell of insecticides and spray with the furniture inside. Acceptability correlated with the spray coverage achieved, although the most frequent suggestion for improvement was to increase the understanding of the objectives of spraying by the members of the communities. This suggests that it is possible to increase the levels of vector control provided that better awareness in the community is achieved.

Although no causal-effect was documented and villagers did not link symptoms with insecticide spraying, our results confirm that insecticides cannot be applied without discomforts. The use of DDT in an area of high resistance to this compound resulted in low effect against house pests and the perceived uselessness of the intervention. On the other hand, more symptoms were associated with the MOS and ROT treatments (Table V), indicating that the combination of insecticides clearly increased the frequency and severity of immediate undesired effects. The long-term effect of these insecticides on the environment and human health awaits investigation. These results introduce new considerations in the application of these strategies designed to retard the appearance of resistance to insecticides currently available for public health. Implementation of prevention strategies rather than vector control measures will reduce the use of insecticides and therefore the contact and possible sideand long-term effects on humans.

\section{Acknowledgements}

This study was funded by IRAC/GCPF (The Insecticide Resistance Action Committee of the Global Crop Protection Federation), with further contributions from companies participating in the Public Health Working Group of IRAC/GCPF, viz: Agrevo, Bayer, Cheminova, FMC, Mitsui Toatsu, Novartis, Rhone Poulenc, Sumitomo and Zeneca.

\section{References}

I. Rafatjah $\mathrm{H}$. The problem of resurgent bed-bug infestation in malaria eradication programmes. J Trop Med Hyg 1971;74:53-56.

2. Njunwa KJ, Lines JD, Magesa SM, Mnzava AE, Wilkes TJ, Alilio M, et al. Trial of pyrethroid impregnated bednets in an area of Tanzania holoendemic for malaria. Part I. Operational methods and acceptability. Acta Trop 1991;49:87-96.

3. Baker EL Jr, Warren M, Zack M, Dobbin RD, Miles JW, Miller S, et al. Epidemic malathion poisoning in Pakistan malaria workers. Lancet | $978 ; 1: 3 \mid-34$.

4. de Zulueta J, Mujtaba SM, Shah IH. Malaria control and long-term periodicity of the disease in Pakistan. Trans R Soc Trop Med Hyg 1980;74:624-632.

5. Moretto A. Indoor spraying with the pyrethroid insecticide lambdacyhalothrin: effects on spraymen and inhabitants of sprayed houses. Bull World Health Organ 1991;69:591-594.

6. Chester G, Sabapathy NN, Woollen BH. Exposure and health assessment during application of lambda-cyhalothrin for malaria vector control in Pakistan. Bull World Health Organ 1992;70:615-619.

7. Bouma MJ, Nesbit R. Fenitrothion intoxication during spraying operations in the malaria programme for Afghan refugees in North West Frontier Province of Pakistan. Trop Geogr Med 1995;47: I2-I4. 8. Charlwood JD, Alecrim WD, Fe N, Mangabeira J, Martins VJ.A field trial with lambda-cyhalothrin (ICON) for the intradomiciliary control of malaria transmitted by Anopheles darlingi Root in Rondonia, Brazil. Acta Trop 1995;60:3-13.

9. Richter ED, Chuwers P, Levy Y, Gordon M, Grauer F, Marzouk J, et al. Health effects from exposure to organophosphate pesticides in workers and residents in Israel. Isr J Med Sci 1992;28:584-597.

10. Ames RG, Howd RA, Doherty L. Community exposure to a paraquat drift. Arch Environ Health 1993;48:47-52.

II. Le Quesne PM, Maxwell UC, Butterworth ST. Transient facial sensory symptoms following exposure to synthetic pyrethroids: a clinical and electrophysiological assessment. Neurotoxicol 1980;2: I-I I. 12. He F, Sun J, Han K, Wu Y, Yao P,Wang S, et al. Effects of pyrethroid insecticides on subjects engaged in packaging pyrethroids. $\mathrm{Br} J$ Ind Med 1988;45:548-55।.

13. Tabashnik BE. Managing resistance with multiple pesticide tactics: theory, evidence, and recommendations. J Econ Entomol 1989;82:1263-1269.

14. Penilla RP, Rodriguez AD, Hemingway J, Torres JL,Arredondo-Jimenez Jl, Rodriguez MH. Resistance management strategies in malaria vector mosquito control. Baseline data for a large-scale field trial against Anopheles albimanus in Mexico. Med Vet Entomol 1998;12:217-233. 15. Scarborough ME, Ames RG, Lipsett MJ, Jackson RJ. Acute health effects of community exposure to cotton defoliants. Arch Environ Health 1989;44:355-360.

16. Srivastava HC, Kant R, Bhatt RM, Sharma SK, Sharma VP. Epidemiological observations on malaria in villages of Buhari PHC, Surat, Gujarat. Indian J Malariol 1995;32: I 40-I52.

17. Zar JH. Biostatistical analysis. 2nd edition. Englewood Cliffs: PrenticeHall, 1984.

18. McCullag P, Nelder JA. Generalized linear models. 2nd edition. New York: Chapman and Hall, 1989.

19. Rodríguez AD, Penilla RP, Rodríguez MH, Hemingway J, Betanzos AF, Hernandez-Avila JE. Knowledge and beliefs about malaria transmission and practices for vector control in Southern Mexico. Salud Publica Mex 2003;45: I10-116.

20. Sampath TRR, Yadav RS, Sharma VP, Adak T. Evaluation of lambdacyhalothrin-impregnated bednets in a malaria endemic area of India. Part I. Implementation and acceptability of the trial. J Am Mosq Control Assoc 1998; 14:431-436. 